JPPUMA: Jurnal Ilmu Pemerintahan dan Sosial Politik UMA (Journal of Governance and Political Social

UMA), 9 (2) (2021): 163-172, DOI: 10.31289/ippuma.v9i2.4464

JPPUMA: Jurnal Ilmu Pemerintahan dan Sosial Politik UMA

(Journal of Governance and Political Social UMA)

Available online http://ojs.uma.ac.id/index.php/jppuma

\title{
Politics Comes from Daily Life Reflections (Armada Riyanto Political Philosophy Perspective)
}

\author{
Juli Antonius Sihotang* \\ Department of Theological Philosophy, Sekolah Tinggi Filsafat Teologi Widya Sasana, Malang, \\ Indonesia
}

Received: 16 November 2020; Reviewed: 09 December 2020; Accepted: 02 July 2021

\begin{abstract}
This article explores and describes the chaotic world of Indonesian politics, which has often become a theme of public discussion, especially politicians in many events. Problems focused on the world of politics were campaigns, debates, tactics, and arguments from politicians. It makes the world of politics often show the winners and the losers. At the same time, the real world of politics is also a realm to reflect on daily life. In reflecting, he invited a politician to explore the nobility of his dignity and others. Brought him to discover the depths of his life with others while at the same time discovering the truth. This discovery made a politician realize that the world of politics was not only about campaigns, debates, tactics, and arguments. To gain this problem, using the theoretical reference from Armada Riyanto's thinking. The author collected the data through a literature study and analyzed it qualitatively by collecting and studying various books, journal articles, and other sources related to the author's writings. Hence, the differences, similarities, and novelties of the author's pieces could be seen. This study concluded that the depth of life and truth guides a politician not to be naive in following orders, carrying out the law, and which must defeat politicians in tactics and strategies. Politics should be synonymous with honesty, justice, and brotherhood among politicians.
\end{abstract}

Keywords: Politics; Politician; Reflection; Depth of Life; Truth

How to Cite: Sihotang, J.A., (2021), Politics Comes from Daily Life Reflections (Armada Riyanto Political Philosophy Perspective), JPPUMA: Jurnal Ilmu Pemerintahan dan Sosial Politik UMA (Journal of Governance and Political Social UMA), 9 (2) (2021): 163-172

\begin{tabular}{lr}
\hline *Corresponding author: & ISSN 2549-1660 (Print) \\
E-mail: julianlisieux@gmail.com & ISSN 2550-1305 (Online)
\end{tabular}




\section{INTRODUCTION}

The background of this study relates to politics, which makes most people immediately think about the campaigns, debates, tactics, and arguments of politicians. The fact that automatically makes many people, especially politicians, forget that politics has a very broad scope of discussion since de facto politics permeates almost all aspects of human life. It makes politics a topic of debate on many occasions. It cannot even deny that politics often create new problems within a group, between individuals, society, and the nation, especially in Indonesia.

This fact makes the community, especially political actors in the country, unaware that politics is also a realm to reflect on daily life. In reflection, each person is led to explore the nobility of his dignity, his fellow human beings, and the sovereignty of living with him. In other words, reflection is a process for each individual to see the depths of life and discover what the truth is. It is the reason why the activity of reflection carves and displays human life and dignity. Hence, politics will not interest other people at all(Riyanto, 2009).

The activities carried out in the reflection process indicated whether each person was presently aimed to only listening, following orders, carrying out laws and obligations naively or wisely? Does such an attitude also show whether his presence as a person who wants to reach the depths of life and truth or not? This fact will illustrate that the process of reflection is a lifelong pilgrimage for anyone to reach the depths of life and discover what truth is in daily life. Absolutely, in a framework, a person is with himself, others, and God(Riyanto, 2011).

This relationship framework aimed to make every individual aware that did not find the beauty of life in any ideology or belief. In reality, God did not create an ideology but a human being. Therefore it is significant that every individual realizes that anything that is meant to be a political truth or religious belief serves the presence of a human being. Hence, love is the highest expression and peak of the beauty of life that humans often find through the depths of life and truth(Riyanto, 2013).

Armada Riyanto is a religious leader (Father/Pastor) from the Catholic church, author of various books, one of the lecturers, and Chancellor of the Widya Sasana Theological Philosophy College, Malang. His humanist, sharp, and critical thinking in his writings in various books, especially on politics, is the reason for the author to analyze Indonesian politics today, so that Armada Riyanto's thoughts, which were used as the author's basic idea in this article, are useful for other people (readers) as well as scholars and politician. Therefore, the world of politics is realized and able to become a sphere for every politician to make their life as individuals who reflect on daily life experiences.

Otherwise, the study conducted by various parties in previous studies on political themes has been quite a lot. The multiple studies include Reflection on the Judicialization of Politics Phenomenon in Legal Politics The Establishment of the Constitutional Court and the Decisions of the Constitutional Court (Officer, 2016), Beyond Politicians, Towards Statement: Christian Ethical Reflections (Siburian, 2017), Citizenship Education: A Reflection on Responding to the Challenges of Today's Indonesia (Saleh \& Hidayah, 2017), Symbolic Violence in Putu Wijaya's Guts: Literature, Politics, and Reflections (Adi, 2018), Candidates for Corrupt Legislative Members: Reflections on the 2019 Election in Malang (Allah, Hadityo Anugrah and Rahman, 2020), Politics as a Path of Happiness: Reflections on Al-Frābī .'s Islamic Social and Political Philosophy (Putri, 2020).

As for several previous studies described above by the author, we can see that political themes are also open to collective reflection. It can be seen and found that politics is not always about campaigns, debates, tactics, and arguments from politicians. Should also use Politics to reflect by the whole community, especially politicians, on what has happened in the world of politics from the past until now in the context of Indonesia. Hence the reflection carried out through several studies of political phenomena that have occurred, found solutions and answers to all problems of morality, corruption, injustice, depravity, and badness of what has happened in the political world in recent decades in the country.

Several previous studies show that studies that explore the theme of Politics Come from Reflections on Daily Life (Riyanto, 2009, 
2011)have not to be done. Therefore the author explored the theme through several political research themes as above, even though the pieces of the studies are not the same. However, the author found out that the political themes above have a relationship with the music being studied by the author since they have a relationship in terms of politics, especially since the authors' reflections in previous studies on political phenomena that are currently happening.

\section{RESEARCH METHOD}

The method used by the author in this study was a literature study with a qualitative analysis of what was happening in the current and previous political world by exploring and studying several sources related to the investigation being carried out by the author, especially by exploring previous research studies in the form of books, journal articles, information from the internet and other sources related to the author's research theme. Hence, the author showed the differences, similarities, and new findings from the research theme being worked on in scientific writing.

\section{RESULTS AND DISCUSSION Indonesian Political Thought}

Indonesian political thought has existed since the rise of the modern Nationalism movement. This movement was born around 1900-1910, pioneered by students and young scholars; this group views the contemporary world as a challenge in people's lives and believes that they are future leaders. This group's thinking is based on the understanding that people are backward, helpless, oppressed, and need renewal in their lives. Meanwhile, the leadership of the Nationalism movement that existed before the war in the country occurred remained among the various small groups of educated people since the educated at this time were the people who got a good place in social life.

In December 1949, when the Dutch gave independence to Indonesia, represented in Soekarno and Hatta, the country's situation then began to enter a stage of change. It is why intellectuals are highly sought after and needed by the state to become government officials, cabinet ministers, civil servants, cultivators of various issues of political belief in the Ministries of Religion, Information, Education, and members of brain trust groups. It is undeniable that many of them are leaders and holders of significant roles in political parties.

The role of Soekarno and Hatta then became the basis for new hope of a glorious future for all Indonesian people, even though for Soekarno himself, his current position had made him often attacked by various parties, as well as by bad people. There were often expressions circulating domestically and abroad that stated that all Indonesian people did not desire his presence. This fact was revealed when Soekarno said,

"I'm not a perfect man. Every creature makes mistakes. On sacred days I apologize to my people for the mistakes I know I've made, and for the mistakes I am not aware of. Perhaps one of my faults was that I always pursued a goal and not solving the problems. I keep trying to subdue the situation or recreate the conditions, so that they can be used as a way to achieve what is being pursued. As a result, even though I tried so hard for my people, I became a victim of malicious attacks."(Adams, 1966).

Soekarno and Hatta, who became leaders of the state, then instilled in all Indonesian people radiant dawn, sunny day, and a day full of hope to be lived and lived in the days that followed after they had experienced gloomy and suffering times. As a result of colonial rule by the Dutch. Soekarno and Hatta considered understanding as an attitude of Nationalism. A new perspective and spirit with the belief "our people will be alive, and not like a carcass as now."

This attitude of Nationalism which then indirectly also became the basis for Soekarno and Hatta to show all Indonesian people where this nation's political thinking would go next. Otherwise, the attitude of Nationalism instilled by Soekarno and Hatta illustrates that Indonesian political thought from the beginning was based on awareness, struggle, and expectation to rise together to interpret yesterday, today, and tomorrow to create a better life. , happy and prosperous for all people.

The attitude of Nationalism is then instilled in all Indonesian people in 3 ways. 
First, make all people aware that they have a past, as a beautiful time. Second, to invest awareness in the people that they have the present, as a dark time. Third, igniting enthusiasm and expectation to all people for a radiant light in the future, sunny day, presence, and responsibility to realize all promises that all Indonesian people have heard. (Feith, Herbert, and Castles, 1988).

Hereafter, in the 1955 General Elections, with the completion of the general foundations of the parliamentary system, it automatically became very clear to every reflective Indonesian that they had to find certain ways to answer the various problems facing the nation within the framework of a modern civil order that seemed inescapable. Resolved, especially in the face of increasing primordial discontent and political conflicts. Elections that are sincerely expected to bring about a change in the nation and state structure, in fact, only make the atmosphere of the country increasingly vague and uncertain. (Geertz, 1992).

This fact indirectly showed that all events and challenges in life are a central process in daily life to be reflected on. Where reflection is not to divide and scatter various aspects of life, however, to reunite a life that has been torn apart by the careless and erroneous analysis of a few irresponsible people. The reflection referred to here Hence consists of two stages. The first stage, review, tends to divide, classify unity, and be indifferent to others who are not with it. This reflection investigates, analyzes various experiences, and the subject is reduced from multiple life experiences. The second stage, review, is admiration since it is faced with a mystery. In short, the second stage of reflection restores relationships, togetherness, and empathy for each other, whoever he is(Hariyadi, 1994).

\section{Politics is a Paradigm}

Politics is one of the disciplines that crave and aim to reach ethical truths in everyday life; it is thus also started to be a paradigm. Politics is a paradigm, which has a fundamental character of consistency, in which the paradigm must presuppose a rational, philosophical, and practice consistency. Reasonable consistency means referring to the recta ratio. Namely, it makes sense. Meanwhile, what is meant by intellectual consistency here is the discovery of the identity of living together. The last consistency, namely practical consistency, means the determination to voice and fight for the principles of truth in daily life.

Facts have shown that politics is a paradigm, so we must understand the daily life of human beings not in a narrow sense but in itself broad and unique in politics contained all the virtues and principles of living together. However, must also realize that in politics, human life is divided, differentiated, and at the same time, the meaning of human presence is reduced. Humans, in other words, are included in the real world and the virtual world Dunia(Riyanto, 2018). Where in their daily life, humans are always in the experience of togetherness with other people, both known and completely unknown. It is the reason that humans live in a wide and unique reality since humans are always in a relationship with each other, the world, and with God himself.

Based on Armada Riyanto, this understanding means humans have a nature to seek and reach for the truth. His life can never be finished and stopped since humans are always trying to find and find their true nature. In other words, human life should not be understood only in the knowledge of right and wrong, due to right and wrong belonging to the understanding of reason, so it does not apply in the context of daily life. The fact is seen in everyday life, where not a few people have wrong knowledge, however always seek and live a good, true, friendly, empathetic life towards the lives of others, even those they do not know. His life is truly born and flows from true virtue.

While otherwise, people who often appear to have the right knowledge are very eager to become opportunists, jokers, and main characters on the theatrical stage, namely in daily life and in the world of politics. All actions and efforts are carried out by such people, only to manifest superficial self desires and, in many cases, to make other people's lives miserable. It is a picture of daily life, especially in Indonesia, about the world of politics and the politicians who live and reign in it. (Riyanto, 2001).

De facto, not a few politicians were the owners of double agent status. On the one side, they are eager to eradicate the corruptors; otherwise, they turn out to be one of the 
corruptors, even the leader of the corruptors who must be eliminated from this country. Hence the effort to fight against corruption in the political world becomes very difficult, especially to find out the friend or the foe. It is undeniable that acts of bribery have flared up like a tradition and are indiscriminate in the realm of the party, which in popular language is referred to as congregational corruption.

A fact of life shows that every politician will always try to protect other politicians if they want to be safe from the snares of corruption and the law. In public, they are like orators, models, and heroes of anti-corruption slogans. However, they are Thanos as told in one of the best films in the world, namely The Avengers. An antagonist who can eliminate every hero who is defending the earth and dares to fight him. While in the political realm, they are Thanos who can take people's and state's money away and even take other people's lives(Denny, 2006a).

Thanos in the world of politics is seen in the relationship of one party to the opposition party. The existence of the opposition is not a means for every party to be open to criticism for the development of a better and more mature party, however rather as an enemy that must remove from political life. Then, is the existence of the opposition like a pebble on the road that must remove before being stepped on? Or is the resistance the embodiment of a snowball? The opposition grew to be very large since the wider community supported it. Of course, since they honestly fight for everything good and right for the benefit of the community and their party, not even to fish in troubled waters.

A brief description of the existence of the opposition can be seen from the story of changes in power in the past during the Suharto era of the golden regime where almost all aspects/fields of life are highly dependent on the level of satisfaction and dissatisfaction of the wider community. It is why the opposition is such a tree, while the satisfaction and dissatisfaction of the community is such the ground. The more people feel dissatisfied, the more the opposition will grow into a tree that is fertile, growing, and bearing fruit. Otherwise, if the wider community is satisfied with the existing situation, the opposition will only grow as it is(Denny, 2006b).

\section{Riyanto's Armada Political Philosophy}

The first understanding that must possess in this discussion is the knowledge that political philosophy is not the same as political science (Alfian, 1980). ${ }^{1}$ Where based on Armada Riyanto, the fundamental difference between the two lies in their perspective. Political philosophy has a philosophical perspective, while political science has a philosophical perspective (Barents, 1960) does not have it. Through the thoughts of philosophers from ancient times to the present, which was initiated by Socrates (referred to as the founder of Political Philosophy), political philosophy is a realm to seek wisdom, create new civilizations, create justice, make human life reasonable, and make the world of daily human life. It becomes beautiful and charming.

Armada Riyanto pointed out that there are five urgent missions of political philosophy to be realized and explored together about politics, especially for every politician, including the following:

Political philosophy has an urgent and important mission to prevent every politician from being naive in politics: 1) Preventing and overcoming brutal violence in the future; 2) Promote fairness or equality in living together; 3) Decide on the taste of human freedom; 4) Continuously criticizing society for the sake of humane construction and conscientization.

The urgency of political philosophy as described by Armada Riyanto shows that politics must also be reflective of daily life. Hence, politics is busy with campaigns, debates, talks, short-sighted tactics and strategies, usurping the throne, corruption. (Huntington, 2003) ${ }^{2}$ And stage plays as

${ }^{1}$ At the time of the Proclamation of Indonesian Independence in 1945, there was not a single Indonesian citizen who graduated from a university with a degree in Political Science. However, in early 1946 when the capital city of the Republic of Indonesia moved from Jakarta to Yogyakarta, various academies in various branches of science were established, one of which was the Academy of Political Science, which was officially established in 1948.

${ }^{2}$ Corruption is the behavior of state officials who deviate from the general norms of public service. However, corruption occurs in all types of society. However, it was more common and intense in one 
politicians have put on in recent decades. They are all a group of people who pretend to have amnesia so that they seem not to know and do not remember that politics should involve everything that is the goal of the whole society (shared dreams), and not at all as one's personal goals (private goals)(Budiardjo, 1992).

This fact is a scene that makes many Indonesians increasingly fed up, skeptical, and pessimistic of politicians and the political world from day today. (Pendapa, 2020). ${ }^{3}$ All the promises and hopes made to

group than others and more serious in the early days of modernization than after it. This fact shows that there is a close relationship between corruption and rapid economic growth.

3 Currently, many people believe that all things related to the world of politics are not good. Politics is connoted as deception, lies, fraud, hostility, or something that can all be bad. Society assumes that everyone who enters the world of politics will be dirty, far from good, and will act incompatible with humanity. Although not everything about politics is bad, their thinking is already twisted, making it difficult to change. They will always say that they should shun all things related to politics. This has resulted in the decline and collapse of public confidence in politics. It is mentioned that people are judged to no longer believe in politics. The more often you follow political news, the public's trust in political life is getting worse. The Director of Indonesian Political Indicators, Burhanuddin Muhtadi, assessed that the intensity of the people in following political news also affected the public's poor perspective on politics. So can say that following this political news is one of the factors that cause people's bad views about the world of politics itself. Based on information disseminated through newspapers or television and online media or social networks, 72 percent of respondents concluded that politicians tend to talk about their good. In addition, people are pessimistic that politicians will fulfill their political promises and accuse politicians of being a group of people pursuing personal gain. Referring to this, we as a society should understand and give a grace period for politicians to fulfill all their promises. We should be the ones who accompany them to realize what He has promised, to understand what was once a shared desire and aspiration. In addition, we need to know that nothing is instant in this world; changing to a better realm, of course, will also take time. Based on a study conducted in mid-June 2013, Burhanuddin said that the public no longer believes the wider community in the campaign were just a picture of the husks that had been blown away by the wind so that they flew everywhere. The promises and hopes that the public has heard from politicians are thus very difficult to become a reality, even though the bearers of these promises and hopes have succeeded and achieved their heart's desires. These politicians are a picture of the current Malinkundang disobedient to their mothers, namely the people who have been loyal and desperately supported them from the beginning.

These politicians are like individuals who make the political sphere (Luisi, 1990) ${ }^{4} \mathrm{As}$ a theatrical stage, they always act as the main actors based on the scenario that has been neatly arranged and matured long in advance. It is this attitude which, for Armada Riyanto, is a picture of individuals who only listen, follow orders, carry out laws and obligations naively (naively), so that they are very easily impressed and tempted by the pleasures of this world, especially thrones and wealth. They embrace falsehood, the status quo, and anything that can fulfill their desires and happiness, even though the truth must reveal to bring about prosperous life changes and the

in politics because of the bad image of political institutions in the people's eyes. Of the 2,290 respondents in the study, 67 percent said they were not interested in politics. In addition, public trust in political institutions is also poor. Starting from 58 percent of respondents who said they did not believe in political parties, followed by respondents who did not believe in politicians, ministers, DPR, and the president. This distrust of society has until now been a troubling polemic, and we should solve it together. Not easily influenced by circumstances and being able to filter first by considering the good or bad of something is an important thing that must be owned by our society today.

4The term politics refers to activities related to power, namely to gain or maintain it. In a narrow sense, politics means all activities that want to influence or achieve power distribution. Meanwhile, in a broad sense, politics means the overall involvement in various public services and their impacts in the economic, social, cultural, and educational fields. 
bonum commune. (Go, 2004) $)^{5}$ In the nation and state.

This naive attitude also makes these politicians very fond of lulling and provoking the public, especially their supporters, to wallow in indifference to the injustices that occur in daily life. In other words, the politicians who live in a naivete attitude daily deny themselves the truth and the injustices that occur around their lives, since de facto it does not harm them, especially since these politicians are comfortable with everything they have from results as the main actor in the theatrical world of politics.

\section{Politics Come from Daily Life Reflections}

The reality that occurred as well as the picture in the minds of the wider community regarding the political world of the country showed that politics which came from the reflection of daily life, which became the idea of Armada Riyanto in describing his political philosophy, is urgent and contextual at this time to be explored and lived together as a never-ending process for anyone, especially for every politician. Such politics for Armada Riyanto is discussed with politics that must also reflect daily life, which is most likely born from his experience and reflection on what has happened in the political world in recent decades.

Armada Riyanto's thoughts on politics rooted in daily life reflections are broadly seen from the five urgent missions of his political philosophy. He showed that politics has a very broad scope in everyday life, so that politics is also called a science of skill or science that has a variety of techniques. It is why, based on Aristotle, politicians should be individuals who have the capacity and ability to overcome all the technical skills that exist in daily life.

A politician, otherwise, can become a person like the description of Aristotle's thought, specifically here in Armada Riyanto's idea if the politician bases his appreciation on the reflection of daily life since, through activities of thinking, will lead his life to mental activities that overcome all events. Everyday

${ }^{5}$ This term is not easy to interpret in Indonesian. However, the meaning is a more or less public interest, and common welfare symbolizes everything humans need to live humanely. life, seeking the depths of life, and discovering what the truth is. He reflects on all life experiences that have been experienced before and now to interpret tomorrow better and the future, not only for his own life but also for others.

Humans as creatures who have reason and conscience should always reflect on the history of life that has happened before, not first to see, know, and learn from what has happened in the past, but to carry out a deep reflection and down to earth, so that efforts are made continuously for the sake of a meaningful life. This fact shows that the process of review leads everyone to search for the deep meaning of life from all experiences and events that have occurred before and now so that he has a better future. Hence through everything that has happened, this life is realized is not a mere routine. Moreover, the realm to keep yourself busy,

\section{Reaching the Depths of Life and Truth}

The pilgrimage of every human life, which is filled with various meanings at all times and experiences based on Armada Riyanto, is a fact that human life is also filled with multiple tensions, reconciliation (harmony) living together, and the existence of a relationship between the sacred (Holy term which here would encapsulate the divine, pious, and lives in virtue) with the secular/profane. Humans live in reality, where the world they step on is filled with fascinating and boring things, making them experience what is called the master's weapon since he is stranded on an island of his own making. The fact that often makes people unknowingly have turned away even left what religiosity in their lives is,

It is why it is significant for everyone to always enter into the process of reflection in daily life, which is filled with various meanings and mysteries so that awareness arises in him that everyday experiences are very valuable and important for anyone. A process that makes a person able to live up to the fact that the fullness of life is not always found in various life experiences that are beautiful, pleasant when achieving success, being happy, and having something valuable. 
Instead, he finds that the true fullness of life is found in life's difficult, challenging, hopeless, and lost events, even in the event of the death of a loved one. He realized that his property, throne, family, and life were nothing. However, a deposit from the Creator was free to be taken anytime and anywhere by the Owner. It is a fact that every individual should always be aware of, where the true fullness of life will never be owned by people who only occupy themselves with debates, tactics, and arguments, campaigns, being the main actors on stage plays, jokers and opportunists everywhere. However, by everyone who has the will, open attitude, loyalty,

He was transformed into a friendly, sensitive, empathetic, sincere, and honest person in living his pilgrimage with others in his daily life. His life presents the relationship between your neighbor and me. A relationship that gives the truth that both are in the realm of communication and togetherness in daily life. A person is present as a person who is diligent, manages, maintains, and presents the beauty of his life and that of others. Hence the relationship between your neighbor and me is a process of becoming so that both of them gave birth to us. Our term must be understood not as a combination of my neighbor and me, however a fact of coexistence. In this coexistence, a community is formed, in which nature is communicative. It does not provide space and opportunity for any attitude of hypocrisy, reduction and set aside every person who lives and lives in it. This coexistence, in other words, is a relation with the principle that if one suffers, the other feels it, and vice versa(Riyanto, 2018).

Without reducing the role of other politicians, individuals who base their lives on reflections of daily life in Indonesia, both in the social and political spheres, are President Jokowi and Basuki Tjahaja Purnama (Ahok). They both always live in characters who are not easy to be naive (naive) to everything that is found and experienced in daily life. President Jokowi and Basuki Tjahaja Purnama (Ahok) embody a person who always reflects on his life with himself, others, society, and God. That's what makes them live as individuals who are critical, creative, and wise. The appreciation that makes them also live in honesty, justice, and brotherhood towards each other, whoever they are (friends or opposition). In short,(Community Survey on Jokowi's Performance in Handling Covid-19, nd) ${ }^{6}$ and Basuki Tjahaja Purnama (Ahok) (Survey on the level of citizen satisfaction with Ahok, nd) ${ }^{7}$ First of all, dedicated his life not for himself, however especially for the sake of others, namely others, society, and God.

\section{CONCLUSION}

The pilgrimage of life is a strand of various experiences of every human being in the world. Each person with himself, others, and God in a bandage of sad-happy, challengesuccess, birth-death. A fact that requires humans to continue to mix and rage with all their experiences in daily life. Therefore, he becomes a mature, empathetic, and wise person in his life in front of others and his God. He lives everything you want others to do to

6 From various survey institutions, one of them is Indonesia Politic Opinion (IPO), released the results of a survey related to public satisfaction with President Jokowi, especially for now in a handlingCOVID-19 pandemic is in the satisfying stage, whereas a result, $63 \%$ of the people were satisfied with the performance of President Joko Widodo. Based on the survey results released Saturday (4/7/2020), the IPO measured the public's assessment of aspects related to handling the COVID-19 pandemic. This assessment measured the weaknesses and strengths of the government's performance. The survey was conducted on 8-25 June 2020, involving 1,350 respondents in 30 provinces. The survey used online interview research methods or by telephone. The confidence level of the survey results is 97 percent, with a margin of error of 3.54 percent.

7 Showed that various surveys show that the majority of the people were satisfied with Ahok's performance, especially when he was still serving as the Governor of DKI Jakarta; one of them is The Populi Center Institute released survey results showing that the level of satisfaction of the people of DKI Jakarta with leadership DKI Governor Basuki Tjahaja Purnama or Ahok increase. Based on the researchers Populi Center, the level of satisfaction with the performance of the DKI Jakarta Provincial Government was 70 percent in February and rose to 73.3 percent in April 2016. The satisfaction level with Ahok's performance was 73.5 percent in February to 73.7 in April 2016. Meanwhile, the satisfaction of DKI residents against Ahok's leadership was as much as 81.5 percent in April 2016, 85.5 percent in February, and 77.7 percent in December 2015. 
you, do the same to your neighbor. The world of politics with all its offers often makes the politicians who are there selfish, busy with debates, fighting tactics and strategies, opportunist, jokers, and main actors in the theatrical stage. Politics is also a realm for reflecting on daily life in my strands with myself, neighbors, society, and God. Reflection makes every individual (politician) enter into seeking to discover the depths of life and what the truth is. These searches and discoveries then turn a person into someone who is not easily naive to everything he finds and experiences in his life, be it his daily life or his existence in the vortex of the political world. Instead, he is transformed into a critical, mature, and wise person. His life flows from the source of clear water, which is a true virtue. A person born from the reflection of daily life is individual who automatically show the wider community that politics does not always show campaigns, debates, tactics and strategies, corruption, opportunist and jokers, and main actors in the theatrical stage of the political world, however, is also a place to bring and change character. Someone becomes an honest person, a warrior for justice, and makes everyone, whoever he is, with all backgrounds and status as brothers. He is a politician who was born from politics comes from daily life reflection.

\section{BIBLIOGRAPHY}

Adams, C. (1966). Bung Karno Penjambung Lidah Rakjat Indonesia. Gita Karya.

Adi, S. (2018). Kekerasan Simbolik dalam Nyali Karya Putu Wijaya: Karya Sastra, Politik, dan Refleksi. Jurnal Mozaik Humaniora, 18(1), 114.

Alfian. (1980). Ilmu Politik di Indonesia. Gadjah Mada University Press.

Allahi, H. A., \& Rahman, F. (2020). Kandidasi Calon Anggota Legislatif Koruptor: Refleksi atas Pemilu 2019 di Malang. JIIP: Jurnal Ilmiah Ilmu Pemerintahan, 5(1), 46-57. https://doi.org/10.14710/jiip.v5i1.7085

Barents, J. (1960). Ilmu Politik. P. T. Pembangunan.

Budiardjo, M. (1992). Dasar-Dasar Ilmu Politik. Gramedia Pustaka Utama.

Denny, J. A. (2006a). Membangun Demokrasi Sehari-hari (F. Surdiasis (ed.)). LKis.

Denny, J. A. (2006b). Para Politisi dan Lagunya (Fransiskus Surdiasis (ed.)). LKis.

Feith, Herbert dan Castles, L. (1988). Pemikiran Politik Indonesia 1945-1965. LP3ES.
Geertz, C. (1992). Politik Kebudayaan. Kanisius.

Go, P. (2004). Hak Asasi Manusia dalam Etika Politik. In Etos dan Moralitas Politik. Kanisius.

Hariyadi, M. (1994). Membina Hubungan Antarpribadi Berdasarkan Prinsip Partisipasi, Persekutuan, dan Cinta menurut gabriel Marcel. Kanisius.

Huntington, S. P. (2003). Tertib Politik Pada Saat Masyarakat yang Sedang Berubah. PT Raja Grafindo Persada.

Luisi. (1990). Menentukan Pilihan Politis. Kanisius.

Pendapa, L. (2020). Pandangan Masyarakat Mengenai Politik. https://lpmpendapa.com/opini/pandanganmasyarakat-mengenai-politik/ dan https://nasional.kompas.com/read/2015/0 4/11/15150041/Parpol.dan.Persepsi.Publik ?page=all

Perwira, I. (2016). Refleksi Fenomena Judicialization of Politics pada Politik Hukum Pembentukan Mahkamah Konstitusi dan Putusan Mahkamah Konstitusi. Jurnal Konstitusi, 13(1), 25-47.

Putri, E. W. (2020). Politik Sebagai Jalan Kebahagiaan: Refleksi Filsafat Sosial Dan Politik Islam Al-FĀrābī. Jurnal Al Fuad, 4(1), 25-34.

Riyanto, A. (2001). Hak Asasi Manusia: Pergumulan Etika dan Politik. In A. Riyanto (Ed.), HAM Telaah Filosofis Teologis. Dioma.

Riyanto, A. (2009). Politik, Sejarah, Identitas, Postmodernitas. STFT Widya Sasana.

Riyanto, A. (2011). Berfilsafat Politik. Kanisius.

Riyanto, A. (2013). Menjadi Mencintai. Kanisius.

Riyanto, A. (2018). Relasionalitas Filsafat Fondasi Interpretasi: Aku, Teks, Liyan, Fenomen,. Kanisius.

Saleh, M., \& Hidayah, Y. (2017). Pendidikan Kewarganegaraan: Sebuah Refleksi Menjawab Tantangan Indonesia Kini. Prosiding Konferensi Nasional Kewarganegaraan III, November, 284-288.

Siburian, T. (2017). Melampaui Politisi, Menuju Negarawan: Refleksi Etis Kristiani. Societas Dei: Jurnal Agama Dan Masyarakat, 4(1), 6464.

Survei Masyarakat Atas Kinerja Jokowi Menangani Covid-19. (n.d.). Diambil 17 Oktober 2020, dari https://news.detik.com/berita/d5080373/survei-ipo-63-masyarakat-puasatas-kinerja-jokowi-tangani-covid-19

Survei Tingkat Kepuasan Warga Terhadap Ahok. (n.d.). Diambil 17 Oktober 2020, dari https://www.liputan6.com/news/read/249 1978/survei-tingkat-kepuasan-wargaterhadap-ahok-815-persen $\% 0 \mathrm{~A} \% 0 \mathrm{~A}$ 
Juli Antonius Sihotang, Politics Comes from Daily Life Reflections (Political Philosophy Perspective 